\begin{tabular}{|c|c|}
\hline 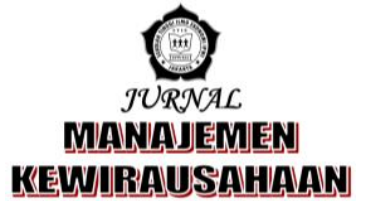 & $\begin{array}{r}\text { p-ISSN 1858-1048 } \\
\text { e-ISSN 2654-9247 } \\
\text { http://ejurnal.stieipwija.ac.id/index.php/jmk } \\
\text { DOI: http://dx.doi.org/10.33370/jmk.v17i1.393 } \\
\text { Jurnal Manajemen Kewirausahaan Vol. 17 No. 01 - Juni } 2020 \\
\text { Submit: 01 Nov 2020; Review: 07 Mei 2020; Publish: 30 Jun } 2020\end{array}$ \\
\hline
\end{tabular}

\title{
ANALISIS PERAMALAN IHSG DENGAN TIME SERIES MODELING ARIMA
}

\section{(ANALYSIS OF INDONESIA COMPOSITE INDEX (IHSG) FORECASTING WITH ARIMA TIME SERIES MODELING)}

\author{
Oleh: \\ Riana Susanti ${ }^{1)}$, Askardiya Radmoyo Adji ${ }^{2}$ \\ santihoesodo@gmail.com ${ }^{1)}$, ahoesodo@gmail.com $\left.{ }^{2}\right)$ \\ Sekolah Tinggi Ilmu Ekonomi IPWI Jakarta ${ }^{1,2)}$
}

\begin{abstract}
Stock price prediction is something that always attracts investors and other stakeholders' interest in the stock market. In stock trading, the upcoming Indonesia Composite Index (IHSG) movement' can be used as a basis for decisions making for investment actors. This study aims to test The Autoregressive Integrated Moving Average (ARIMA) time series model to predict IHSG on the Indonesia Stock Exchange. ARIMA is a model for generating estimates from historical data. The data in this study were collected from the daily IHSG from 2 January 2017 to 3 January 2018 and obtained from monthly reports published by the Indonesia Stock Exchange. The prediction results indicate that this model is quite accurate for forecasting. The results showed that the ARIMA model that has the best performance to predict IHSG was the ARIMA model $(7,3,1)$.
\end{abstract}

Keywords: Stock Price Prediction, Indonesia Composite Index, Time Series, ARIMA

\begin{abstract}
ABSTRAK
Prediksi harga saham merupakan hal yang selalu menarik minat investor dan pemangku kepentingan lain terhadap pasar saham. Dalam perdagangan saham, pergerakan IHSG yang akan datang dapat digunakan sebagai dasar untuk melakukan pengambilan keputusan pelaku investasi. Penelitian ini bertujuan menguji model time series Autoregressive Integrated Moving Average (ARIMA) untuk memprediksi IHSG di Bursa Efek Indonesia. ARIMA adalah model untuk menghasilkan perkiraan dari data historis. Data dalam penelitian ini dikumpulkan dari IHSG harian dari 2 Januari 2017 sampai 3 Januari 2018. Data diperoleh dari laporan bulanan yang dipublikasikan Bursa Efek Indonesia. Hasil prediksi menunjukkan bahwa model ini cukup akurat untuk peramalan. Hasil penelitian menunjukkan bahwa model ARIMA yang memiliki kinerja terbaik untuk memprediksi IHSG, yaitu model ARIMA $(7,3,1)$
\end{abstract}

Kata Kunci: Prediksi harga saham, IHSG, Time Series, ARIMA

Jurnal Manajemen Kewirausahaan Vol. 17 No. 01 - Juni 2020

LP2M Sekolah Tinggi Ilmu Ekonomi IPWI Jakarta 


\section{PENDAHULUAN}

Prediksi dan analisis IHSG merupakan hal kondusif bagi investor yang berinvestasi di pasar saham. Hal ini dikarenakan hasil prediksi tersebut dapat memberikan referensi kepada investor dalam melakukan aktifitas perdagangan dan investasi mereka di pasar saham. Harga di pasar saham berfluktuasi dari waktu ke waktu karena pembelian dan penjualan yang berkelanjutan. Oleh karenanya, investor di pasar saham akan tertarik untuk menganalisis pergerakan harga saham tersebut.

Metode yang digunakan untuk menganalisis saham dan membuat keputusan investasi jatuh ke dalam dua kategori besar yaitu analisis fundamental dan analisis teknikal. Pada dasarnya, kedua pendekatan ini memiliki tujuan yang sama yaitu untuk mendapatkan rekomendasi pembelian saham dengan harga lebih rendah dan menjual dengan harga lebih tinggi untuk mendapatkan pengembalian investasi yang baik.

Analisis fundamental melibatkan analisis karakteristik perusahaan dalam memperkirakan nilainya. Seorang analis fundamental akan memperhatikan faktor-faktor fundamental. Yang menjadi fokus adalah penentuan nilai sebenarnya atau nilai intrinsik dari suatu saham berdasarkan kapasitas penghasilannya saat ini dan di masa depan. Mereka akan membeli saham ketika harga pasar di bawah nilai intrinsiknya.

Analisis teknikal mengambil pendekatan yang sangat berbeda. Analisis ini tidak peduli tentang nilai perusahaan. Pelaku analisis teknikal ini sering disebut chartists. Para chartist ini hanya tertarik pada pergerakan harga di pasar saham. Dengan menggunakan harga, volume, dan open interest statistic, analis teknikal menggunakan grafik untuk memprediksi pergerakan saham di masa depan. Analisis teknikal berupaya untuk menguji data historis dalam memprediksi harga saham guna melakukan pembelian ataupun penjualan suatu instrumen investasi. Prediksi perkembangan harga saham dengan analisis teknikal dapat menggunakan 3 prinsip dasar yaitu 1) Harga saham mencerminkan informasi yang relevan. 2) Informasi tersebut ditunjukkan oleh perubahan harga di waktu yang lalu. 3) Perubahan harga saham akan mempunyai pola tertentu bersifat repetitive (Husnan, 2000).

Terdapat beberapa kategori yang termasuk indikator teknikal yaitu: indikator momentum, analisis garis tren, indikator filter, teori siklus, indikator volume, analisis pola, dan analisis gelombang. Data ini berasal dari data harga saham yang berurutan (time series). Indikator bisa memberikan informasi jangka pendek atau panjang, membantu mengidentifikasi tren atau siklus di pasar, atau menunjukkan kekuatan harga saham menggunakan tingkat dukungan dan resistance (Lawrence, 1998).

Analisis deret waktu merupakan bagian penting dalam statistik, yang menganalisis kumpulan data untuk mempelajari karakteristik data dan membantu dalam memprediksi nilai serial di masa mendatang berdasarkan karakteristiknya. Peramalan ini penting dalam bidang-bidang seperti keuangan, industri, dll (Chen, 2014).

Model Autoregressive Moving Average (ARMA) adalah metode penting untuk mempelajari deret waktu. Konsep model Autoregressive (AR) dan Moving Average (MA) dirumuskan oleh Yule, Slutsky, Walker, dan Yaglom (Chen, 2014). Autoregressive Integrated Moving Average (ARIMA) didasarkan pada Model ARMA. Perbedaannya adalah bahwa Model ARIMA mengubah data nonstasioner menjadi data stasioner sebelum diolah. Model ARIMA sering disebut juga sebagai model Box-Jenkins karena pertama kali dipopulerkan oleh Box dan Jenkins. Model Autoregresif Integrated Moving Average (ARIMA) adalah model yang secara penuh mengabaikan independen variabel dalam membuat peramalan. ARIMA menggunakan nilai masa lalu dan sekarang dari variabel dependen untuk menghasilkan peramalan jangka pendek yang akurat. ARIMA cocok jika observasi dari deret waktu (time series) secara 
statistik berhubungan satu sama lain (dependen).

Hasil penelitian mengenai peramalan dengan metode ARIMA dengan menggunakan data IHSG tahun 2006 menunjukkan bahwa model ini cukup akurat untuk peramalan dengan prosentase kesalahan absolut rata-rata adalah sebesar 4,14\% (Sadeq, 2008). Penelitian lain untuk memprediksi IHSG periode harian dengan metode analisis ARIMA menunjukkan bahwa harga saham terdahulu berpengaruh dalam meramalkan harga saham sekarang pada IHSG di BEI dengan periode 2 Januari 2013 sampai 30 Desember 2013 (Yani, 2018).

$$
\text { Analisis lain dengan }
$$

menggunakan data dari Shanghai Composite Index, Model ARIMA digunakan untuk menganalisis Shanghai Composite Index pada Oktober 2016 dan memprediksi perubahan Shanghai Composite Index pada bulan November dan Desember 2016. Hasil penelitian menunjukkan bahwa dalam dua bulan terakhir tahun 2016 Indeks Komposit Shanghai akan mengalami kenaikan kecil (Li, Yang, \& Li, 2017).

Memiliki pengetahuan yang sangat baik tentang pergerakan harga saham di masa depan secara signifikan akan membantu investor dan personal di bidang keuangan (Uma, Sundar, \& Alli, 2013). Oleh karena itu perlu model untuk menganalisa trend harga saham dengan informasi yang relevan untuk pengambilan keputusan. Metode ARIMA direkomendasikan karena model ini akan mentransformasikan data time series, sehingga pendekatan peramalan ini akan lebih baik daripada meramalkan secara langsung karena menghasilkan data yang lebih akurat (Alwadi, 2011).

Peramalan adalah suatu proses yang tidak pernah ada akhirnya. Data terbaru akan muncul oleh karena itu perlu diduga dan diperiksa kembali model yang baru.

\section{TUJUAN PENELITIAN}

Berdasarkan latar belakang yang sudah diuraikan di atas, penelitian ini bertujuan membuktikan metode ARIMA dapat dipakai dalam prediksi IHSG harian, dengan demikian dapat diketahui apakah nilai IHSG terdahulu berpengaruh terhadap peramalan IHSG masa mendatang.

\section{TELAAH LITERATUR PENGEMBANGAN HIPOTESIS Analisis Teknikal}

Analisis teknikal adalah bentuk penilaian investasi yang menganalisis harga di masa lalu untuk memprediksi harga di masa depan. Evaluasi investasi dan identifikasi peluang perdagangan saham dilakukan dengan analisis tren statistik yang dikumpulkan dari aktivitas perdagangan, seperti pergerakan harga dan volume perdagangan dalam suatu saham atau aset keuangan tertentu dan kemudian menyimpulkan dari sejarah yang digambarkan kemungkinan tren masa depannya.

Banyak riset yang dilakukan mengenai manfaat melakukan analisis teknikal di pasar saham dengan berbagai hasil yang berbeda. Tujuan dari berbagai analisis ini adalah untuk mengeksplorasi dan menguji apakah analisis teknikal memiliki kekuatan untuk memprediksi pergerakan harga saham. Hasil dari analisis ini akan membantu investor dalam membuat keputusan beli dan jual.

Penelitian pada saham-saham sektor perbankan LQ45 dilakukan oleh Pramono et.al (2013) dengan menggunakan metode MACD (Moving Average Convergence Divergence), RSI (Relative Strength Index), SO (Stochastic Oscillator) dan strategi buy and hold. Hasil yang didapatkan adalah strategi menggunakan metode buy and hold tepat untuk dijalankan agar mendapat keuntungan di pasar saham pada sektor perbankan. Pengamatan lain dilakukan oleh Mohamed Masry (2017), menyimpulkan bahwa dengan menggunakan metode teknik analisis Simple Moving Average didapatkan hasil bahwa strategi ini dapat digunakan untuk mendapat keuntungan di pasar saham Mesir. 


\begin{abstract}
Penggunaan analisis teknikal dimanfaatkan juga oleh Adebiyi, Adewumi \& Ayo (2014) dalam penelitiannya dengan data New York Stock Exchange dan Nigeria Stock Exchange (NSE). Prediksi dengan menggunakan model ARIMA menghasilkan prediksi yang potensial kuat untuk jangka pendek dan dapat menandingi teknik yang ada untuk prediksi harga saham.
\end{abstract}

\section{Model ARIMA}

Model ARIMA adalah model statistik untuk menganalisis dan meramalkan data time series. Model ini disebut juga dengan Model Box-Jenkins sesuai dengan nama yang mengembangkan model ini dengan intensif yaitu George Box dan Gwilym Jenkins tahun 1976. Model Box-Jenkins merupakan salah satu teknik peramalan model time series yang hanya berdasarkan perilaku data variabel yang diamati (Let the data speak for them selves) (Widarjono, 2005)

Model Box-Jenkins memiliki perbedaan dengan model struktural baik modal kausal maupun simultan. Pada dua model tersebut, persamaan model menunjukkan hubungan antara variabel-variabel ekonomi. Model BoxJenkins dipergunakan karena pergerakan variabel-variabel ekonomi yang diteliti seperti pergerakan nilai tukar, IHSG, dan inflasi sulit dijelaskan oleh teori-teori ekonomi.

Model ARIMA dikembangkan untuk mengatasi ketidakmampuan dari model ARMA (Autoregressive and Moving Average) ketika menghadapi data yang tidak stationer. Data yang tidak stationer atau non stationary data, secara konseptual, adalah data yang sangat sulit untuk dimodelkan. Hal ini disebabkan karena estimasi rata-rata akan berubah dan kadang-kadang variannya pun berubah. Penggunaan non-stationer time series akan berakibat hasil yang diperoleh bisa saja palsu dalam hal bahwa mereka dapat menunjukkan hubungan antara dua variabel di mana salah satu tidak ada.

Untuk mendapatkan hasil yang konsisten dan handal, data nonstasioner perlu ditransformasikan menjadi data stasioner. Berbeda dengan proses non-stasioner yang memiliki varian dan rata-rata variabel yang tidak tetap dekat, atau kembali ke rata-rata jangka panjang dari waktu ke waktu, proses stasioner kembali di sekitar ratarata jangka panjang yang konstan dan memiliki varian konstan independen waktu. Oleh karena itu, ARIMA diperkenalkan untuk mengatasi hal itu, dengan memasukkan unsur integrasi atau data tersebut stasioner pada tingkat berapa.

Dalam membuat model ARIMA, terdapat beberapa tahapan yang harus dilakukan terkait AR, MA, dan integrasi variabel yang tidak stasioner.

Tiga aspek kunci dari model ini adalah 1) Autoregressive, merupakan sebuah model peramalan yang menggunakan hubungan dependen antara observasi dan sejumlah observasi lagged. 2) Integrated, yaitu penggunaan diferensiasi (differencing) pengamatan data mentah (misalnya mengurangi data pengamatan dari data pengamatan pada langkah sebelumnya) untuk membuat time series stasioner. 3) Model Moving Average, adalah model yang menggunakan ketergantungan antara observasi dan error residual dari model moving average yang diterapkan observasi lag.

Peramalan dengan Model ARIMA efekif dalam jangka pendek. Beberapa literatur menyebutkan syarat minimal data point historis adalah 72. Model ini akan berfungsi paling baik jika data stabil dengan outlier minimum. ARIMA biasanya lebih unggul daripada teknik smoothing eksponensial jika data dinilai cukup panjang dan korelasi antara pengamatan stabil.

Peramalan dengan metode ARIMA banyak dipergunakan pada banyak bidang, seperti ramalan penjualan, ramalan permintaan suatu produk yang mempengaruhi supply chain, ramalan tingkat kriminalitas, ramalan nilai mata uang, harga saham, indeks saham, dan lainnya.

Penelitian terdahulu berkaitan dengan peramalan harga saham dilakukan oleh Lilipaly, Hatidja \& Kekenusa (2014) dengan menggunakan 
data harga saham Bank BRI Tbk tahun 2011 sampai Oktober 2014. Didapatkan harga saham maksimum adalah dengan menggunakan model ARIMA $(2,1,3)$. Dari hasil pengujian, data tersebut bisa digunakan untuk memprediksi harga saham bulan November 2014 dengan validasi prediksi yang diambil pada bulan Oktober 2014.

Peramalan di pasar saham dengan teknik analisis ARIMA dilakukan juga oleh Li, Yang \& Li (2017) terhadap Shanghai Stock Index dengan menggunakan data dari Januari 2005 sampai Oktober 2016. Efektivitas hasil peramalan diuji dengan meramalkan Shanghai Composite Index dari bulan Juli 2016 sampai Oktober 2016. Dengan membandingkan nilai prediksi dengan nilai aktual didapatkan bahwa model ARIMA ini dapat memberikan prediksi yang lebih baik.

\section{Peramalan IHSG}

Nachrowi Djalal \& Hardius Usman (2007) melakukan penelitian peramalan IHSG dengan menggunakan metode ARIMA dan GARCH dan membandingkan hasil dari dua metode tersebut. Dengan menggunakan data harian dari 3 Januari 2005 sampai dengan 2 Januari 2006, hasil yang didapatkan adalah bahwa model ARIMA yang sangat sederhana ini mempunyai kesalahan prediksi yang relatif lebih kecil bila dibandingkan dengan Model GARCH.

Penelitian lain yang melakukan komparasi dalam memprediksi pergerakan IHSG dan saham Astra International (ASII) dilakukan oleh, Iskandar Zulkarnain (2010). Metode yang digunakan adalah metode ARIMA dan Main Chart + Ichimoku Chart, dengan uji Wilcoxon untuk kedua model tersebut. Hasil penelitian menunjukkan bahwa Main Chart + Ichimoku Chart lebih berlaku dan praktis dibandingkan dengan Model ARIMA.

Memprediksi pergerakan IHSG merupakan masalah praktis yang akan mempengaruhi perilaku investor untuk membeli atau menjual saham. Peramalan atau prediksi dari tren ini akan membantu investor untuk mendapatkan peluang keuntungan di pasar saham.

\section{Kerangka Penelitian}

Kerangka penelitian untuk menganalisis peramalan IHSG dengan time series modeling ARIMA dapat di digambarkan sebagai berikut:

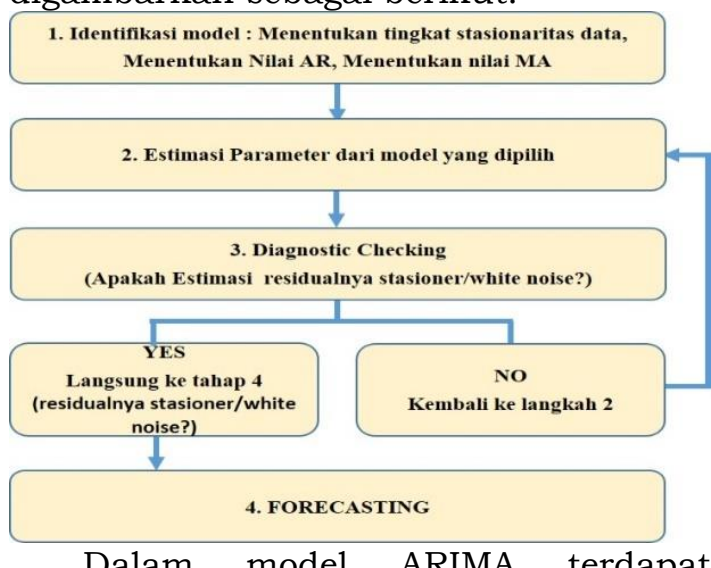
beberapa tahapan yang harus dilakukan terkait dengan penentuan AR, MA, dan integrasi variabel yang tidak stasioner.

Langkah pertama adalah mengidentifikasi model. Untuk menentukan model ARIMA (p,d,q), terlebih dahulu ditentukan nilai $d$ dengan cara melakukan uji stasioneritas. Jika input data tidak stasioner maka dilakukan modifikasi agar data stasioner. Cara melakukannya adalah melakukan proses differencing yaitu mengurangkan nilai data pada suatu periode dengan nilai data periode sebelumnya.

Jika data sudah stasioner, langkah berikutnya adalah menentukan $\mathrm{p}$ dan $\mathrm{q}$ untuk parameter ARIMA dengan cara melihat pola fungsi autokorelasi (ACF) dan autokorelasi parsial (PACF) dari data. Dari hasil pengujian bisa ditentukan kandidat model yang sesuai.

Langkah kedua adalah melakukan estimasi dari parameter yang dipilih. Pendugaan parameter, jika ada lebih dari 1 kandidat yang dipilih maka akan dilakukan estimasi parameter satu persatu. Setelah semua dilakukan estimasi, dipilih model terbaik.

Langkah ketiga, memilih dari model yang terbaik, dilakukan tes diagnostik, yaitu uji signigikansi parameter dan uji asumsi residual. Jika residual berupa 
white noise, berarti model terpilih cocok dengan data. Sebaliknya bila residual tidak berupa white noise, artinya model terpilih bukan merupakan model yang cocok. Sehingga proses akan diulang dari awal lagi atau iterasi. Proses terakhir adalah melakukan forecasting atau peramalan.

Berdasarkan uraian di atas dapat diajukan hipotesis sebagai berikut:

Model ARIMA dapat dipergunakan memprediksi pergerakan IHSG harian.

\section{METODE PENELITIAN Sampel Penelitian}

Populasi penelitian ini adalah semua data Indeks Harga Saham Gabungan (IHSG) di Bursa Efek Indonesia (BEI). Dari populasi ini diambil sampel data penutupan IHSG mulai periode 2 Januari 2017 hingga 3 Januari 2018 (jumlah pengamatan 240 hari perdagangan).

\section{Desain Penelitian}

Penelitian ini adalah penelitian deskriptif kuantitatif. Pengamatan dilakukan pada data historis IHSG untuk selanjutnya sampel populasi penelitian dianalisis sesuai dengan metode statistik yang digunakan. Pemodelan deret waktu yang digunakan adalah Autoregressive Integrated Moving Average (ARIMA). Model ini kemudian digunakan untuk menghasilkan nilai mendatang untuk membuat perkiraan harga IHSG.

\section{Operasionalisasi Variabel}

Indeks Harga Saham Gabungan (IHSG) adalah Indeks yang mengukur pergerakan semua saham yang tercatat di Bursa Efek Indonesia (BEI). Indeks ini mencakup pergerakan harga seluruh saham biasa dan saham preferen yang tercatat di BEI. Dasar perhitungan IHSG adalah jumlah nilai pasar dari total saham yang tercatat pada tanggal 10 Agustus 1982. Jumlah nilai pasar adalah total perkalian setiap saham tercatat (kecuali untuk perusahaan yang berada dalam program restrukturisasi) dengan harga di BEJ pada hari tersebut. Data IHSG yang dipergunakan adalah data yang dikeluarkan oleh Bursa Efek Indonesia.

\section{Metode Analisis}

Analisis data dilakukan dengan menggunakan metode ARIMA. Sebelum melakukan perhitungan dengan menggunakan metode ARIMA, serangkaian uji-uji dilakukan sebagaimana digambarkan dalam kerangka penelitian di atas.

Pertama, pengujian kestasioneran tahap pertama adalah membuat correlogram fungsi autokorelasi. Peneliti menggunakan software Eviews untuk mengamati autokorelasi dan autokorelasi parsial. Apabila koefisien autokorelasinya berbeda dari nol dan signifikan, mengecil secara perlahan membentuk garis lurus, dan semua koefisien autokorelasi parsial mendekati nol setelah lag pertama, maka hal tersebut menunjukkan bahwa data bersifat tidak stasioner.

Uji autokorelasi lain adalah uji unit root Augmented Dickey-Fuller. Data time series memiliki stasioneritas jika perubahan waktu tidak menyebabkan perubahan distribusi. Unit root adalah salah satu penyebab data non-stasioner. Data time series yang memiliki unit root menunjukkan pola sistematis yang tidak dapat diprediksi. Unit root test Augmented Dickey-Fuller akan menghasilkan nilai ADF. Jika data stasioner maka memiliki nilai ADF lebih besar daripada nilai kritis.

Kedua, proses selanjutnya adalah differencing, dilakukan apabila data tidak stasioner. Differencing adalah menghitung perubahan atau selisih nilai observasi. Nilai selisih yang diperoleh dicek lagi apakah stasioner atau tidak. Caranya dengan membuat kembali fungsi autokorelasi correlogram dan unit root test Augmented Dickey-Fuller.

Langkah ketiga yaitu penentuan nilai $\mathrm{p}, \mathrm{d}$, dan $\mathrm{q}$ dalam ARIMA. Proses Autoreggressive Integrated Moving Average dilambangkan dengan ARIMA (p,d,q) dimana $\mathrm{p}$ menunjukkan ordo/derajat autoregressive (AR), d adalah tingkat proses differencing, q menunjukkan ordo/derajat moving average (MA). 
Adalah mungkin suatu series nonstasioner homogen tidak tersusun atas kedua proses itu, yaitu proses autoregressive maupun moving average. Jika hanya mengandung proses autoregressive, maka series itu dikatakan mengikuti proses integrated autoregressive dan dilambangkan ARIMA $(\mathrm{p}, \mathrm{d}, 0)$. Sementara yang hanya mengandung proses moving average, seriesnya dikatakan mengikuti proses integrated moving average dan dituliskan ARIMA (0,d,q).

Keempat, setelah data runtut waktu telah stasioner, langkah berikutnya adalah menetapkan model ARIMA (p,d,q) yang sekiranya cocok (tentatif), maksudnya menetapkan berapa $\mathrm{p}, \mathrm{d}$, dan q. Jika tanpa proses differencing d diberi nilai 0 , jika menjadi stasioner setelah first order differencing d bernilai 1 dan seterusnya. Dalam memilih berapa $\mathrm{p}$ dan $\mathrm{q}$ dapat dibantu dengan mengamati pola fungsi autocorrelation dan partial autocorrelation (correlogram) dari series yang dipelajari.

Kelima, estimasi parameter model ARIMA. Misalkan bentuk model tentatif telah ditetapkan, langkah berikutnya adalah menduga parameternya sebagai berikut 1) Apabila model tentatifnya AR (autoregressive murni), maka parameternya diestimasi dengan analisis regresi dengan pendekatan kuadrat terkecil linear. 2) Apabila modelnya mencakup MA walaupun modelnya ditulis dalam bentuk linear, tetapi cara menghitungnya menggunakan model nonlinear. Biasanya dilakukan melalui 2 tahap yaitu tahap estimasi awal dan estimasi lanjutan, hingga dihasilkan estimasi akhir atas parameter.

Keenam, peramalan. Setelah model terbaik telah ditetapkan, model ini digunakan dalam peramalan. Dalam penelitian ini data peramalan dibandingkan dengan data asli pergerakan saham selama tahun pengamatan.

Ketujuh, pengukuran kesalahan peramalan. Pengukuran kesalahan teknik peramalan ini dapat dilakukan dengan cara menghitung 1) RMSE (Root Mean Squared Error) merupakan akar kuadrat dari MSE (Mean Squared Error)
MSE. Akar kuadrat dipergunakan untuk membuat skala error sama dengan skala target. 2) Mean Absolute Error (MAE) dihitung sebagai rata-rata perbedaan absolut antara nilai target dan prediksi. MAE adalah skor linier yang berarti bahwa semua perbedaan individu rataratanya diberi bobot yang sama. 3) Mean Absolute Percentage Error (MAPE) atau persentase kesalahan absolut rata-rata. MAPE dihitung dengan menggunakan kesalahan absolut pada tiap periode dibagi dengan nilai observasi yang nyata untuk periode itu. Selanjutnya meratarata kesalahan persentase absolut tersebut. Pendekatan ini berguna ketika ukuran atau besar variabel ramalan itu penting dalam mengevaluasi ketepatan ramalan. MAPE mengindikasi seberapa besar kesalahan dalam meramal yang dibandingkan dengan nilai nyata.

\section{HASIL DAN PEMBAHASAN Hasil Penelitian}

Dari hasil pengolahan data yang dilakukan peneliti, berikut ini statistik deskriptif dari variable IHSG yang diamati pada periode dari 2 Januari 2017 sampai dengan 3 Januari 2018. Jumlah observasi dari data yang diamati adalah 240. Selama periode tersebut, IHSG mencapai nilai maksimum di angka 6500,529 dan menyentuh nilai minimum di angka 5250,968. Standar deviasi dari data IHSG adalah 290,2676 dengan rata-rata 5777.315 sehingga varian data tinggi dan kemungkinan tidak stasioner. Data yang kemungkinan tidak stationer ini juga nampak dari grafik yang menunjukkan trend meningkat.

Tabel 1

Statistik Deskriptif IHSG Periode 2 Januari 2017 - 3 Januari 2018

\begin{tabular}{|l|c|}
\hline & CP_IHSG \\
\hline Mean & 5777.315 \\
\hline Median & 5813.741 \\
\hline Maximum & 6500.529 \\
\hline Minimum & 5250.968 \\
\hline Std. Dev. & 290.2676 \\
\hline Skewness & 0.105332 \\
\hline Kurtosis & 2.674873 \\
\hline Observations & 240 \\
\hline
\end{tabular}


Gambar 1

Pergerakan Harga IHSG Periode 3

Januari 2017 - 3 Januari 2018 CP_IHSG

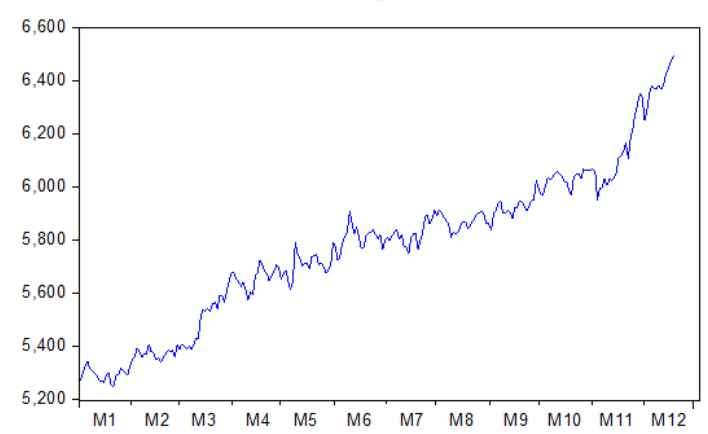

Untuk memastikan data tersebut stationer atau tidak dilakukan uji stationer data dengan Augmented Dickey-Fuller Test.

Tabel 2

Uji Stationer Data dengan Augmented Dickey-Fuller Test

\begin{tabular}{|l|c|c|}
\hline & t-statistic & Probabilitas \\
\hline $\begin{array}{l}\text { Augmented } \\
\text { Dickey-Fuller } \\
\text { test statistic }\end{array}$ & 0.132771 & 0.9676 \\
\hline
\end{tabular}

Hasil tes ADF menunjukkan bahwa p-value adalah sebesar 0.9676, karena lebih besar dari 5\%, menunjukkan bahwa data tersebut mempunyai unit root atau data tidak stationer, karena itu, dilakukan diferensi pada level 1 . Hasilnya ditunjukkan dalam tabel berikut.

\section{Tabel 3}

Uji Stationer Data Augmented DickeyFuller Test - Differencing 1 Level

\begin{tabular}{|c|c|c|}
\hline & t-statistic & Probabilitas \\
\hline $\begin{array}{c}\text { Augmented } \\
\text { Dickey-Fuller } \\
\text { test statistic }\end{array}$ & 16.54612 & 0.0000 \\
\hline
\end{tabular}

Dari hasil tes ADF nilai probablitasnya sudah kurang dari 5\% menunjukkan data sudah stationer pada diferensi level 1.

Pengujian hipotesis dilakukan untuk melihat apakah model ARIMA ini dapat dipergunakan memprediksi pergerakan IHSG harian. Setelah diferensi, hasilnya sudah stationer, kemudian dilakukan pendugaan menggunakan AR dan atau MA.
Hasilnya ditampilkan dalam tabel di bawah ini.

Tabel 4. Estimasi ARIMA

\begin{tabular}{|l|c|c|c|}
\hline & Model 1 & Model 2 & Model 3 \\
\hline C & 4.8127 & 4.7980 & 4.8339 \\
\hline & $(1.703)^{* *}$ & $(1.6203)^{* * *}$ & $(1.9346)^{* *}$ \\
\hline AR(3) & -0.1362 & & \\
\hline & $(0.0629)^{* *}$ & & \\
\hline AR(7) & & & 0.1590 \\
\hline & & & $(0.0647)^{* *}$ \\
\hline MA(3) & & -0.1594 & -0.1497 \\
\hline & & $(0.0590)^{* * *}$ & $(0.059)^{* *}$ \\
\hline R-squared & 0.0188 & 0.0222 & 0.0475 \\
\hline Adjusted R-squared & 0.0110 & 0.0144 & 0.0360 \\
\hline & & & \\
\hline Akaike info criterion & 9.6837 & 9.6803 & 9.6627 \\
\hline Schwarz criterion & 9.7257 & 9.7223 & 9.7187 \\
\hline F-statistic & 2.3908 & 2.8284 & 4.1222 \\
\hline Prob(F-statistic) & $(0.09365)^{* *}$ & $(0.0610)^{*}$ & $(0.007)^{* * *}$ \\
\hline
\end{tabular}

Angka dalam kurung merupakan standard error

** signifikan pada taraf nyata $1 \%$

* signifikan pada taraf nyata $1 \%$

Terdapat 3 model yang berhasil dikembangkan dari model ARIMA, yaitu model 1 atau ARIMA $(3,0,1)$, model 2 atau ARIMA $(0,3,1)$, dan model 3 atau ARIMA $(7,3,1)$. Ketiga model menunjukkan F-statistic signifikan, baik pada level 10\% (model 1 dan model 2) dan signifikan pada level 1\% (model 3).

Untuk menentukan di antara ketiga model yang paling sesuai, maka dilihat dari nilai AIC (Akaike Information Criterion) dan Schwarz Criterion (SC), dimana model yang memiliki nilai AIC dan SC yang terkecil merupakan model paling sesuai. Terlihat bahwa model 1 AIC adalah 9.6837 dan SC adalah 9.7257. Pada model 2 nilai AIC 9.6803 dan SC adalah 9.7223. Sedangkan pada model 3 AIC adalah 9.6627 dan nilai SC adalah 9.7187. Dari hasil ini terlihat bahwa model 3 yang memiliki AIC dan SC terkecil, karena itu, model 3 merupakan model yang paling sesuai.

Setelah diketahui model 3 paling sesuai, maka dilakukan peramalan atau forecasting. Data peramalan dibandingkan dengan data asli pergerakan saham selama periode pengamatan. Hasil peramalan menunjukkan model ARIMA dapat digunakan untuk memprediksi IHSG. Hasilnya ditampilkan dalam gambar berikut: 
Gambar 2

Hasil Peramalan Model 3 ARIMA(7,3,1)

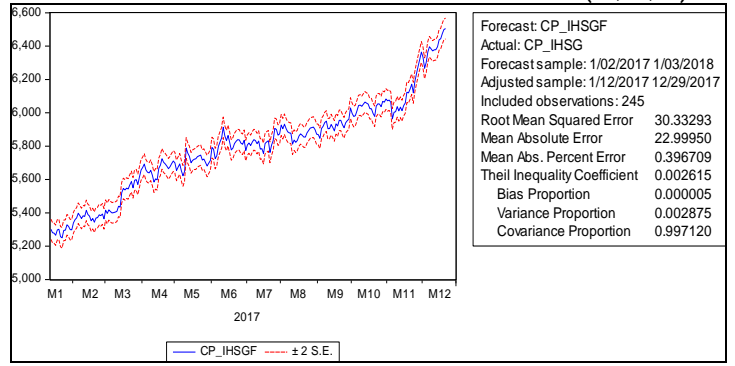

Terlihat bahwa nilai Root Mean Sqared Error (RMSE) sama dengan 30.33293, MAE 22.99950, dan MAPE 0.002615 .

\section{Pembahasan}

Peramalan dengan menggunakan data time series adalah suatu proses memperkirakan nilai di masa mendatang dengan data historis.

Hasil pengujian dalam penelitian ini menunjukkan bahwa metode ARIMA cukup akurat dipergunakan untuk membuat peramalan pergerakan IHSG di Bursa Efek Indonesia. Hal ini sejalan dengan penelitian Sadeq (2008) yang membuat peramalan IHSG pada Bursa Efek Indonesia (BEI) juga penelitian Li, Yang \& Li (2017) pada peramalan Shanghai Stock Index di The Shanghai Stock Exchange (SSE).

Dengan menggunakan data harga saham BRI Tbk tahun 2011 sampai Oktober 2014 penelitian Lilipaly, Hatidja \& Kekenusa (2014) juga menunjukkan bahwa model ARIMA ini dapat dipergunakan untuk peramalan harga saham pada bulan November 2014.

Bagi investor hasil penelitian ini bisa memperkuat beberapa penelitian sebelumnya yang membuktikan bahwa Model ARIMA dapat dipergunakan untuk peramalan di Bursa saham, yaitu untuk prediksi harga saham satu emiten maupun Indeks Harga Saham Gabungan (IHSG).

Dalam penelitian ini Model ARIMA $(7,3,1)$ merupakan model yang paling relevan untuk melakukan peramalan. Pemilihan model yang paling relevan dalam peramalan dengan metode ARIMA ini sangat penting agar untuk mendapatkan hasil peramalan yang paling akurat. Namun demikian untuk peramalan dengan data pada rentang waktu yang berbeda perlu pengujian ulang terhadap alternative model ARIMA yang paling sesuai. Juga pengecekan awal untuk melihat apakah data yang diambil stasioner.

Analisis teknikal merupakan cara praktis untuk memprediksi pergerakan saham. Meski demikian, secara umum analisis teknikal lebih bermanfaat untuk analisis dalam jangka pendek. Model ARIMA ini telah terbukti sebagai opsi yang baik untuk model peramalan dalam jangka pendek pula. Sementara untuk perdagangan dan investasi jangka panjang akan lebih tepat jika menggunakan analisis fundamental sehingga akan didapatkan analisis yang lebih komprehensif

\section{KESIMPULAN \\ Simpulan}

Dari hasil analisis dan pembahasan yang telah diuraikan, maka dapat ditarik kesimpulan bahwa metode ARIMA dapat dipergunakan untuk meramalkan pergerakan IHSG. Model terbaik yang dipergunakan berdasarkan pengujian yang dilakukan adalah ARIMA $(7,3,1)$. Hasil peramalan dengan model ARIMA $(7,3,1)$ ini tidak jauh berbeda dari nilai aktual IHSG.

\section{Saran}

Hasil penelitian ini tidak bisa digeneralisasi untuk periode yang terlalu jauh dari observasi yang dilakukan, sehingga replikasi penelitian ini bisa dilakukan untuk mendapatkan hasil peramalan untuk periode yang lain. Bagi kalangan akademisi, hasil peramalan ini bisa dibandingkan dengan hasil peramalan metode lain, seperti GARCH, Neural Network dan metode lain. Begitupun data yang diobservasi tidak terbatas pada IHSG saja, namun bisa pada data indeks yang lain seperti LQ45, Jakarta Islamic Index, Indeks IDX30 maupun data saham-saham tertentu di Bursa Efek Indonesia. 
DAFTAR PUSTAKA

Adebiyi, A., Adewumi, A., Ayo, C. 2014. Stock price prediction using the ARIMA model. Proceedings UKSim-AMSS 16th International Conference on Computer Modelling and Simulation, UKSim.

Alwadi, S. 2011. Selecting wavelet transforms model in forecasting financial time series data based on arima model. Applied Mathematical Sciences (Ruse), 5 (7):315-326.

Chen, S. E. 2014. The time series forecasting: from the aspect of network. arXiv preprint.

Djalal, N., Usman, H. 2007. Prediksi IHSG dengan model GARCH dan model ARIMA. Jurnal Ekonomi dan Pembangunan Indonesia, 7 (2):199-217.

Husnan, S. 2000. Dasar-dasar Teori Portofolio dan Analisa Sekuritas di Pasar Modal. Yogyakarta: UPPAMP YKPN.

Lawrence, R. 1998. Using neural networks to forecast stock market prices. Department of Computer Science, University of Manitoba.

Li, C., Yang, B., \& Li, M. 2017. Forecasting analysis of shanghai stock index based on ARIMA. MATEC Web of Conferences.

Lilipaly, G. S., Hatidja, D., Kekenusa, J. S. 2014. Prediksi Harga Saham PT. BRI, Tbk. Menggunakan metode ARIMA (autoregressive Integrated moving average). Jurnal Ilmiah Sains: 60-67.

Masry, M. 2017. The Impact of technical analysis on stock returns in an emerging capital markets (ECM's) country: theoretical and empirical study. International Journal of Economics and Finance, 9.

Pramono, A., Soenhadji, I. M., Mariani, S., Astuti, I. 2013. Analisis Teknikal modern menggunakan metode MACD, RSI, SO dan buy and hold untuk mengetahui return saham optimal pada sektor perbankan LQ 45. Bandung: Proceeding PESAT (Psikologi, Ekonomi, Sastra, Arsitektur \& Teknik Sipil).

Sadeq, A. 2008. Analisis prediksi indeks harga saham gabungan dengan metode ARIMA (studi pada IHSG di Bursa Efek Jakarta). Masters Thesis, Program Pascasarjana Universitas Diponegoro.

Uma, D., Sundar, D., Alli, P. (2013, 01 31). An effective time series analysis for stock trend prediction using ARIMA model for nifty midcap-50. International Journal of Data Mining \& Knowledge Management Process, 3:65-78.

Widarjono, A. 2005. Ekonometrika: Teori dan aplikasi untuk ekonomi dan bisnis. Yogyakarta: Penerbit Ekonisia, Fakultas Ekonomi UII.

Yani, A. 2018. Analisis teknikal harga saham dengan metode ARIMA. Jurnal Ilmu Manajemen dan Akuntansi Terapan (JIMAT), 9 (2): 1-16.

Zulkarnain, I. 2010. Akurasi peramalan harga saham dengan model arima dan kombinasi main chart + ichimoku chart. Management Insight, 7(1):59-70. 